\title{
Safety of endoscopic retrograde cholangiopancreatography (ERCP) in patients aged 85 years and older: A single center experience
}

\author{
Ahmed Ramiz Baykan (D), Serkan Cerrah ${ }^{1}$ (D), Sedat Çiftel ${ }^{1}$ (D), Büşra Karahan²(D), Yılmaz Özdemir³ \\ ${ }^{1}$ Clinic of Gastroenterology, Erzurum Regional Training and Research Hospital, Erzurum, Turkey \\ ${ }^{2}$ Clinic of Internal Diseases, Erzurum Regional Training and Research Hospital, Erzurum, Turkey \\ ${ }^{3}$ Clinic of Gastrointestinal Surgery, Erzurum Regional Training and Research Hospital, Erzurum, Turkey
}

\begin{abstract}
Objective: To evaluate the efficacy and safety of endoscopic retrograde cholangiopancreatography (ERCP) in elderly patients ( $\geq 85$ years old).

Material and Methods: Patients who underwent ERCP for any reason within 12 months were evaluated. Patients undergoing ERCP were classified as the elderly group aged 85 years and older or the controls under the age of 85 years.

Results: A total of 1225 patients, 504 males and 721 females, were included in the study. Length of hospital stay, the number of patients in whom precut sphincterotomy was performed in ERCP, and mortality rate showed similar characteristics compared to the control group in patients with advanced age ( $\geq 85$ years old). Except for pancreatitis, there was no significant difference between the groups in terms of complications related to the procedure. Post ERCP pancreatitis was observed significantly less in the elderly group $(p=0.042)$. Pre-cut sphincterotomy was required in a total of $191(15.5 \%)$ patients. In patients who underwent pre-cut sphincterotomy and patients with cholangitis, post ERCP complication rates were not significant between the groups.
\end{abstract}

Conclusion: ERCP is a safe procedure for older patients ( $\geq 85$ years old) as well as young patients.

Keywords: Endoscopic retrograde cholangiopancreatography, elderly, endoscopic procedures

Cite this article as: Baykan AR, Cerrah S, Ciftel S, Karahan B, Özdemir Y. Safety of endoscopic retrograde cholangiopancreatography (ERCP) in patients aged 85 years and older: $A$ single center experience. Turk J Surg 2021; 37 (2): 162-168.

Corresponding Author

Ahmed Ramiz Baykan

E-mail: ahmedbaykan@hotmail.com

Received: 01.01.2021

Accepted: 02.04 .202

Available Online Date: 30.06 .202

o Copyright 2021 by Turkish Surgical Society Available online at www.turkjsurg.com

DOI: $10.47717 /$ turkjsurg.2021.5166

\section{INTRODUCTION}

Today, the average life expectancy is increasing day by day due to the rapid development of technology and medical techniques. In some of the developed countries, people over the age of 65 make up 10\% or more of the population (1). In this direction, while in the past, patients over 65 years old were considered in the advanced age category, today patients over 65 years old are classified as early-aged (65-75), middle-aged (75-85), and elderly (85 years and over) (2).

Endoscopic retrograde cholangiopancreatography (ERCP) continues to be used as the gold standard treatment method in the diagnosis and treatment of hepatobiliary diseases. Comorbid diseases that increase with advanced age raise doubts about the safety of ERCP for the patient. In this direction, this study aimed to evaluate the safety of the ERCP procedure in elderly patients ( 85 years and over) by taking other age groups into consideration.

\section{MATERIAL and METHODS}

\section{Study Group and Endoscopic Procedure}

Patients who underwent ERCP in the gastroenterology department between December 2018-2019 were included in the study. The patients included in the study were examined in detail before the procedure for comorbid diseases, anesthesia risk, the reason for the procedure, and post-operative complications. Patients with missing files were not included in the study. While evaluating the safety of the ERCP procedure in the advanced age group ( 85 years), those under 85 years of age were accepted as the control group. 
ERCP procedure was performed in our clinic by three gastroenterologists with at least five years of ERCP experience using the brand device (Fujinon ED-450XT5). After the procedure, patients were followed for at least two days for complications.

\section{Descriptions}

The scoring system recommended by the "American Society of Anaesthesiologists" was used for risk scoring of anesthesia applied during the procedure (3).

Post-ERCP pancreatitis diagnosis was defined as the complaint of newly developed or worsened abdominal pain and an increase in the amylase level of three times or more 24 hours after the procedure, the need for hospitalization or an extension of the planned hospital stay for at least 2-3 days (4).

In the process-related perforation classification, the classification suggested by Stapfer et al. (5) traumatic and atraumatic duodenal perforations have been managed surgically; however, in the last decade, management has shifted toward a more selective approach. Some authors advocate routine nonsurgical management, but the reported death rate of medical treatment failures is almost $50 \%$. Others advocate mandatory surgical exploration. Those who favor a selective approach have not elaborated distinct management guidelines. Methods: A retrospective chart review at the authors' medical center from June 1993 to June 1998 identified 14 instances of periduodenal perforation related to endoscopic retrograde cholangiopancreatography (ERCP was used. Accordingly, duodenoscope-related duodenum perforations were classified as type 1 , perforations as a result of periampullary sphincterotomy or pre-cut as type 2, perforations that occurred in the bile duct and pancreatic duct while removing the materials used (guidewire), stent, or stone as type 3, and small perforations that occurred as a result of manipulations and characterized by only retroperitoneal air were classified as type 4.

Bleeding due to ERCP was graded according to the classification made by Cotton et al. (6). Accordingly, the hemoglobin value of $<3 \mathrm{~g} / \mathrm{dl}$ and not having the need for transfusion is characterized as mild, the need for transfusion ( $\leq 4$ units) and the need for an interventional (angiographic or surgical) procedure to stop the bleeding as moderate, the need for $\leq 5$ units of transfusion or interventional (angiographic or surgical) procedure was classified as heavy bleeding.

\section{Statistical Analysis}

IBM SPSS Statistics 17 package program was used to statistically compare the findings. In addition, ERCP results were taken as the gold standard. Numerical variables with normal distribution were shown as mean $\pm S D$, while those without normal distribution were shown as mean (minimum-maximum). Categorical variables were shown as numbers and percentages. Mann-Whitney $\mathrm{U}$ and Kruskal-Wallis $\mathrm{H}$ tests were used for comparison of nu- merical variables without normal distribution between groups. Categorical variables were compared with $\times 2$ and Fisher's exact $x 2$ tests. The relationship between quantitative variables was examined with Pearson and Spearman correlation analyses.

\section{RESULTS}

A total of 1225 patients (504 males, 721 females) who underwent ERCP were included in the study. When the patients were classified according to their age, a significant difference was observed in terms of ASA $(p<0.006)$ and comorbid diseases $(p=$ 0.001). There was no significant difference between the patient groups in hospital stay $(p=0.325)$ and sex $(p=0.953)$ (Table 1$)$.

Classification was made according to the coexistence of at least two of the following comorbid diseases; diabetes mellitus, hypertension, coronary artery disease, chronic obstructive pulmonary disease (COPD), cerebrovascular disease (CVD), dementia, chronic renal failure (CRF), liver cirrhosis along with the existing diseases. Comorbid disease status was found to be significantly higher in the advanced age group $(p<0.001)$

When the medications used by the patients were evaluated, a total of 232 (21.2\%) patients in the control group and 87 (65.9\%) patients in the elderly group had a history of using antiaggregant, anticoagulant, or both. When an evaluation was made between the groups, the use of medication was significantly higher in the elderly group $(p<0.008)$.

ERCP was applied for bile duct stones frequently (1034). ERCP procedure was performed on a total of 131 patients with $60 \mathrm{pa}-$ tients due to malignancy and for other reasons (bile duct damage after cholecystectomy, parasitosis, stenosis, etc.) (Table 2).

Common bile duct cannulation could not be performed in 48 patients. Forty-one (3.8\%) of these patients were in the non-elderly group, and 7 (5.3\%) in the advanced elderly group.

Pre-cut was required in 191 (15.5\%) patients. Cannulation was achieved by needle-tipped sphincterotome in 120 (9.7\%) patients and by transpancreatic septostomy in 71 (5.7\%) patients. There was no significant difference in the pre-cut application between the patient and the control group $(p=0.386)$.

There was no significant difference in procedure-related complication rates among endoscopists (complication rates were 6.1\%, $6.3 \%$, and $7.1 \%$ ( $p=0.833$ ). The most common complication due to ERCP was pancreatitis (89 patients), which was followed by bleeding after the procedure with 26 patients. There was no severe bleeding after ERCP. Twenty-two of the patients had mild bleeding, while the remaining four had moderate bleeding. Post-ERCP infectious complications were observed in 16 patients (cholecystitis, cholangitis). A total of 10 patients were affected by the cardiopulmonary system (cardiac arrhythmia, subendocardial myocardial infarction, aspiration, etc.) while perforation was observed in three patients after the procedure. There was only 
Table 1. Demographic characteristics and hospitalization periods of the patients

\begin{tabular}{|c|c|c|c|}
\hline & Control group $(<85$ yo) $n=1093$ & Advanced age ( $\geq 85$ yo) $n=132$ & $\mathrm{p}$ \\
\hline \multicolumn{4}{|l|}{ Sex } \\
\hline Male & $450(36.7 \%)$ & $54(4.4 \%)$ & 0.953 \\
\hline Female & $643(52.5 \%)$ & $78(6.4 \%)$ & \\
\hline ASA score & $2.1 \pm 0.8$ & $3.0 \pm 0.5$ & $<0.006^{*}$ \\
\hline Hospitalization period (day) & $3.6 \pm 1.5$ & $3.7 \pm 1.6$ & 0.325 \\
\hline Drugs & $232(21.2 \%)$ & $87(65.9 \%)$ & $<0.004^{*}$ \\
\hline Antiaggregant & $167(15.3 \%)$ & $60(45.5 \%)$ & \\
\hline Anticoagulant & $40(3.7 \%)$ & $9(6.8 \%)$ & \\
\hline Both & $25(2.3 \%)$ & $18(13.6 \%)$ & \\
\hline Comorbidity & $479(43.8 \%)$ & $120(90.9 \%)$ & $<0.001^{*}$ \\
\hline Diabetes mellitus & $93(7.6 \%)$ & $15(1.2 \%)$ & \\
\hline Hypertension & $80(6.5 \%)$ & $7(0.6 \%)$ & \\
\hline Coronary artery disease & $72(5.9 \%)$ & $15(1.2 \%)$ & \\
\hline COPD & $53(4.3 \%)$ & $9(0.7 \%)$ & \\
\hline CVD & $55(4.5 \%)$ & $7(0.6 \%)$ & \\
\hline Dementia & $5(0.4 \%)$ & $6(0.5 \%)$ & \\
\hline CRF & $26(2.1 \%)$ & $12(1 \%)$ & \\
\hline Cirrhosis & $2(0.2 \%)$ & $1(0.1 \%)$ & \\
\hline At least 2 of them together & $93(7.6 \%)$ & $48(3.9 \%)$ & \\
\hline
\end{tabular}

\section{Table 2. ERCP procedure details}

\begin{tabular}{|c|c|c|c|}
\hline & Control group $(<85$ y) $n=1093$ & Advanced age ( $\geq 85 y) n=132$ & $\mathrm{p}$ \\
\hline \multicolumn{4}{|l|}{ ERCP reason } \\
\hline Stone & $924(84.5 \%)$ & $110(83.3 \%)$ & 0.716 \\
\hline Malign & $45(4.1 \%)$ & $15(11.3 \%)$ & $<0.001^{*}$ \\
\hline Other & $124(11.3 \%)$ & $7(5.3 \%)$ & $0.032^{*}$ \\
\hline \multicolumn{4}{|l|}{ ERCP result } \\
\hline Removal stone & $731(66.9 \%)$ & $95(72 \%)$ & 0.234 \\
\hline Stent ${ }^{* *}$ & $321(29.4 \%)$ & $30(22.7 \%)$ & 0.115 \\
\hline Non-cannulation & $41(3.8 \%)$ & $7(5.3 \%)$ & 0.386 \\
\hline Pre-cut & $167(15.2 \%)$ & $24(18.1 \%)$ & 0.387 \\
\hline Pre-cut sphincterotomy & $102(9.3 \%)$ & $18(13.6 \%)$ & 0.112 \\
\hline Transpancreatic sphincterotomy & $65(5.9 \%)$ & $6(4.5 \%)$ & 0.514 \\
\hline Complication & $131(12 \%)$ & $13(9.8 \%)$ & 0.475 \\
\hline Perforation & $3(0.2 \%)$ & 0 & 0.405 \\
\hline Pancreatitis & $85(7.8 \%)$ & $4(3 \%)$ & $0.042^{*}$ \\
\hline Bleeding & $22(2 \%)$ & $4(3 \%)$ & 0.448 \\
\hline Infectious (cholangitis, cholecystitis) & $13(1.1 \%)$ & $3(2.2 \%)$ & 0.302 \\
\hline Cardiopulmonary & $8(0.7 \%)$ & $2(1.5 \%)$ & 0.346 \\
\hline ERCP related mortality & & & 0.645 \\
\hline During the procedure & $1(0.09 \%)$ & 0 & 0.728 \\
\hline After the procedure & $1(0.09 \%)$ & $1(0.7 \%)$ & 0.516 \\
\hline
\end{tabular}


Table 3. Binary logistic regression analysis for ERCP-related complications

\begin{tabular}{|l|c|c|c|}
\hline & Odds ratio & $\mathbf{9 5 \%}$ Cl & p \\
\hline Age & 1.02 & $0.99-1.06$ & 0.07 \\
\hline Cholangitis & 1.3 & $0.6-2.6$ & 0.40 \\
\hline Pre-cut & 0.89 & $0.3-2.5$ & 0.84 \\
\hline Comorbid diseases & & & \\
\hline Coronary artery disease & 0.48 & $0.7-3.0$ & 0.44 \\
\hline Diabetes mellitus & 0.11 & $0.1-0.8$ & 0.06 \\
\hline Hypertension & 0.15 & $0.2-1.2$ & 0.07 \\
\hline Cerebrovascular disease & 0.99 & $2.6-3.7$ & 0.99 \\
\hline Dementia & 2.9 & $0.5-17.4$ & 0.22 \\
\hline Cirrhosis & 0.62 & $0.1-2.5$ & 0.5 \\
\hline
\end{tabular}

retroperitoneal air in the $\mathrm{CT}$ scans of the patients who developed perforation. They were considered as type 4 perforation.

When evaluated in terms of post-ERCP pancreatitis, the incidence of pancreatitis was observed less in the elderly patient group than in the control group $(p=0.042)$. Death due to ERCP occurred in three patients. One of the deaths occurred during the procedure and the other two occurred during their follow-up in the hospital after the procedure.

Pre-procedure cholangitis was present in 109 patients in total. Complications related to ERCP were observed in six (6.3\%) of these patients. The patients with cholangitis were similar in terms of complications between the elderly and control groups $(p=0.687)$.

\section{DISCUSSION}

As the average age increases worldwide, the elderly population is increasing day by day. With increasing age, bile duct pathologies are more common. Accordingly, in our study, we evaluated the risks of ERCP, which is the gold standard in diagnosis and treatment in hepatobiliary pathologies, in elderly patients by taking other age groups into consideration. As a result, no significant difference was observed in ERCP complications between other age groups and elderly patients.

Half (50.7\%) of the 1225 ERCP procedures performed in our hospital in one year consisted of patients aged 65 and over, the geriatric patient group. The elderly age group over the age of 85 made up $10.8 \%$ of all ERCP performed.

Considering the reasons for ERCP, the most common reason was bile duct stones in both groups. It was observed that performing the procedure due to malignancy was significantly more frequent in the elderly group than in the non-elderly group.

Many studies report that the patient's comorbidity, except cirrhosis, has no effect on ERCP-related complications $(7,8)$. In our results, we determined that comorbid diseases do not cause an increase in ERCP complications. In our study, a total of three patients had a diagnosis of liver cirrhosis. There was no post-ERCP complication in these patients with Child A cirrhosis. As a matter of fact, in some studies conducted in this direction, complications after ERCP observed in patients with cirrhosis were higher in children B and $C$, and there was no increase in complication rates in patients with child $A$ cirrhosis $(9,10)$.

An interesting result of our study is that although the ASA score is significantly higher in elderly patients, the complication rates do not make a significant difference in both groups. A similar situation was described in a study by Galeazzi et al. (11) and the ASA scoring system was evaluated as a qualitative index rather than a quantitative index, which is insufficient to define the complexity of the geriatric population, and a comprehensive geriatric assessment (CGA) was proposed to be applied to geriatric patients as an alternative.

The frequency of complications due to ERCP varies between 5-17\%. (11-15). In our study, our complication rate due to ERCP was $11.8 \%$. When studies evaluating the safety of ERCP in patients aged 90 and over are reviewed, it is seen that the overall complication rates related to ERCP vary between 5-8\% (16-18). In our study, there were a total of 45 patients aged 90 years and over. In these patients, ERCP-related complications occurred in two of our patients (4.4\%).

Pancreatitis is one of the most common and important complications of the ERCP procedure. It has been reported that post-ERCP pancreatitis is seen less frequently in elderly patients due to less response to traumas caused by atrophy, fatty infiltration, and fibrosis that develop in pancreatic tissue with advancing age $(19,20)$. While Finkelmeier et al. have reported the frequency of post-ERCP pancreatitis as $5.2 \%$ in patients under 80 years of age in their study including 758 patients, they found this rate as $0.9 \%$ in patients aged 80 and over. Similarly, Han et al. (21), in their study involving 624 patients, have stated that the frequency of post-ERCP pancreatitis was lower and its severity 
was lower in patients over the age of 80 compared to the young age group. In our study, we found that the rate of post-ERCP pancreatitis was significantly lower in the elderly group compared to those without advanced age (7.8\% vs. 3\%).

During ERCP, pre-cut is needed at a rate of 5-31.5\% (22-24). We needed pre-cut at a rate of $15.6 \%$ to provide cannulation. Our pre-cut requirement was similar in the elderly and control groups $(p=0.386)$. We did not observe a significant difference between the patient groups in the risk of post-ERCP complications and the patients who had pre-cut. It is not clear whether pre-cut increases the risk of post-ERCP complications $(25,26)$. Bailey et al. (27) have stated that $90 \%$ of the cases were pre-incised after cannulation failure at least 15 times during the procedure and that the high rate of post-ERCP pancreatitis in patients with pre-cut was the result of these unsuccessful trials.

Finkelmeier et al. (19) have reported procedure-related bleeding up to 3 times in patients over the age of 90, but Fritz et al. (28) have stated that there was no significant difference in post-ERCP bleeding in patients over 80 years old compared to young people. Han et al. (21), similar to our study, have found no significant difference in terms of bleeding although antiaggregant and anticoagulant use was significantly higher in the 80-year-old group compared to the younger group. In our study, in patients using dual antiaggregant drugs before ERCP one of the drugs was stopped if it had a high cardiac risk. Patients using Warfarin or new generation anticoagulants were switched to low molecular weight heparin.

Cholangitis is a situation where the ERCP process should be carried out urgently. Studies suggest that the mortality risk of cholangitis is related to the timing of drainage rather than age (29-33). We applied an early period ( $<48$ hours) ERCP to our patients with cholangitis and we did not find the association of cholangitis with an increased risk of complications in the elderly patient group.

The limitation of our study is that we did not know the procedure time, and a homogeneous classification could not be made before the procedure as the study was designed retrospectively, and the patients were treated with a structured classification for the operation.

As a result, ERCP is a very safe procedure that can be applied in elderly patients by experienced hands.

Ethics Committee Approval: The approval for this study was obtained from Health Sciences University Erzurum Regional Training and Research Hospital Ethics Committee (Decision No: 2020/02-19, Date: 20.01.2020).

Peer-review: Externally peer-reviewed.

Author Contributions: Concept - A.R.B.; Design -S.C.; Supervision - A.R.B.; Data Collection and/or Processing - S.C..; Analysis and/or Interpratation - B.K.; Literature Review - S.C., Writing Manuscript - A.R.B.; Critical Reviews - Y.Ö.
Conflict of Interest: The authors declare that they have no conflict of interest.

Financial Disclosure: The authors declared that this study has received no financial support.

\section{REFERENCES}

1. Yıldız T. Gercek yaş (Real age). Turkish J Geriatr 2006; 9(3): 195-6. [CrossRef]

2. Alterovitz SSR, Mendelsohn GA. Relationship goals of middle-aged, young-old, and old-old Internet daters: an analysis of online personal ads. J Aging Stud 2013; 27(2): 159-65. [CrossRef]

3. Hocevar LA, Fitzgerald BM. American Society of Anesthesiologists Staging. 2019. [CrossRef]

4. Cotton PB, Lehman G, Vennes J, Geenen JE, Russell RCG, Meyers WC, et al. Endoscopic sphincterotomy complications and their management: an attempt at consensus. Gastrointest Endosc 1991; 37(3): 383-93. [CrossRef]

5. Stapfer M, Selby RR, Stain SC, Katkhouda N, Parekh D, Jabbour N, et al. Management of duodenal perforation after endoscopic retrograde cholangiopancreatography and sphincterotomy. Ann Surg 2000; 232(2): 191-8. [CrossRef]

6. Cotton PB, Lehman G, Vennes J, Geenen JE, Russell RCG, Meyers WC, et al. Endoscopic sphincterotomy complications and their management: an attempt at consensus. Gastrointest Endosc 1991; 37(3): 383-93. [CrossRef]

7. Freeman ML. Complications of endoscopic biliary sphincterotomy: a review. Endoscopy 1997; 29(4): 288-97. [CrossRef]

8. Moreira VF, Arribas R, Sanroman AL, Meroño E, Larena C, Garcia M, et al. Choledocholithiasis in cirrhotic patients: is endoscopic sphincterotomy the safest choice? Am J Gastroenterol 1991; 86(8): 1006-10. [CrossRef]

9. Inamdar S, Berzin TM, Berkowitz J, Sejpal D V, Sawhney MS, Chutanni $R$, et al. Decompensated cirrhosis may be a risk factor for adverse events in endoscopic retrograde cholangiopancreatography. Liver Int 2016; 36(10): 1457-63. [CrossRef]

10. Adler DG, Haseeb A, Francis G, Kistler CA, Kaplan J, Ghumman SS, et al. Efficacy and safety of therapeutic ERCP in patients with cirrhosis: a large multicenter study. Gastrointest Endosc 2016; 83(2): 353-9. [CrossRef]

11. Galeazzi M, Mazzola P, Valcarcel B, Bellelli G, Dinelli M, Pasinetti GM, et al. Endoscopic retrograde cholangiopancreatography in the elderly: results of a retrospective study and a geriatricians point of view. BMC Gastroenterol 2018; 18(1): 38. [CrossRef]

12. Rustagi T, Jamidar PA. Endoscopic retrograde cholangiopancreatography-related adverse events. General overview. Gastrointest Endosc Clin N Am 2015; 25(1): 97-106. [CrossRef]

13. Cho DH, Park GT, Oh JE, Chung CW, Yoo GJ, Kim SR, et al. A single institution's experience of endoscopic retrograde cholangiopancreaticography in the eldery patients: outcomes, safety and complications. Korean J Gastroenterol 2011; 58(2): 88-92. [CrossRef]

14. Cocking JB, Ferguson A, Mukherjee SK, Giancola G. Short-acting general anaesthesia facilitates therapeutic ERCP in frail elderly patients with benign extra-hepatic biliary disease. Eur J Gastroenterol Hepatol 2000; 12(4): 451-4. [CrossRef] 
15. Han SJ, Lee TH, Kang BI, Choi HJ, Lee YN, Cha SW, et al. Efficacy and safety of therapeutic endoscopic retrograde cholangiopancreatography in the elderly over 80 years. Dig Dis Sci 2016; 61(7): 2094-101. [CrossRef]

16. Christoforidis E, Vasiliadis K, Blouhos K, Tsalis K, Tsorlini E, Tsachalis T, et al. Feasibility of therapeutic endoscopic retrograde cholangiopancreatography for bile duct stones in nonagenarians: a single unit audit. J Gastrointestin Liver Dis 2008; 17(4): 427-32. [CrossRef]

17. Hui CK, Liu CL, Lai KC, Chan SC, Hu WHC, Wong WM, et al. Outcome of emergency ERCP for acute cholangitis in patients 90 years of age and older. Aliment Pharmacol Ther 2004; 19(11): 1153-8. [CrossRef]

18. Mitchell RMS, O'Connor F, Dickey W. Endoscopic retrograde cholangiopancreatography is safe and effective in patients 90 years of age and older. J Clin Gastroenterol 2003; 36(1): 72-4. [CrossRef]

19. Finkelmeier F, Tal A, Ajouaou M, Filmann N, Zeuzem S, Waidmann O, et al. ERCP in elderly patients: increased risk of sedation adverse events but low frequency of post-ERCP pancreatitis. Gastrointest Endosc 2015; 82(6): 1051-9. [CrossRef]

20. Lillemoe KD. Pancreatic disease in the elderly patient. Surg Clin North Am 1994; 74(2): 317-44. [CrossRef]

21. Han SJ, Lee TH, Kang B II, Choi HJ, Lee YN, Cha SW, et al. Efficacy and safety of therapeutic endoscopic retrograde cholangiopancreatography in the elderly over 80 years. Dig Dis Sci 2016; 61(7): 2094-101. [CrossRef]

22. Robison LS, Varadarajulu S, Wilcox CM. Safety and success of precut biliary sphincterotomy: Is it linked to experience or expertise? World J Gastroenterol 2007; 13(15): 2183-6. [CrossRef]

23. Harewood GC, Baron TH. An assessment of the learning curve for precut biliary sphincterotomy. Am J Gastroenterol 2002; 97(7): 1708-12. [CrossRef]

24. Figueiredo FAF, Pelosi AD, Machado L, Francioni E, Freitas G, Hatum $P B$, et al. Precut papillotomy: a risky technique not only for experts but also for average endoscopists skilled in ERCP. Dig Dis Sci 2010; 55(5): 1485-9. [CrossRef]
25. Berry R, Han JY, Tabibian JH. Difficult biliary cannulation: historical perspective, practical updates, and guide for the endoscopist. World J Gastrointest Endosc 2019; 11(1): 5-21. [CrossRef]

26. Tang Z, Yang Y, Yang Z, Meng W, Li X. Early precut sphincterotomy does not increase the risk of adverse events for patients with difficult biliary access: a systematic review of randomized clinical trials with meta-analysis and trial sequential analysis. Medicine (Baltimore) 2018; 97(36): e12213. [CrossRef]

27. Bailey AA, Bourke MJ, Kaffes AJ, Byth K, Lee EY, Williams SJ. Needleknife sphincterotomy: factors predicting its use and the relationship with post-ERCP pancreatitis (with video). Gastrointest Endosc 2010; 71(2): 266-71. [CrossRef]

28. Fritz E, Kirchgatterer A, Hubner D, Aschl G, Hinterreiter M, Stadler B, et al. ERCP is safe and effective in patients 80 years of age and older compared with younger patients. Gastrointest Endosc 2006; 64(6): 899-905. [CrossRef]

29. Tohda G, Ohtani M, Dochin M. Efficacy and safety of emergency endoscopic retrograde cholangiopancreatography for acute cholangitis in the elderly. World J Gastroenterol 2016; 22(37): 8382-8. [CrossRef]

30. Parikh MP, Wadhwa V, Thota PN, Lopez R, Sanaka MR. Outcomes associated with timing of ercp in acute cholangitis secondary to choledocholithiasis. J Clin Gastroenterol 2018; 52(10): e97-102. [CrossRef]

31. Lee HS, Chung MJ, Park JY, Bang S, Park SW, Song SY, et al. Urgent endoscopic retrograde cholangiopancreatography is not superior to early ERCP in acute biliary pancreatitis with biliary obstruction without cholangitis. PLoS One 2018; 13(2): e0190835. [CrossRef]

32. Tan M, Schaffalitzky de Muckadell OB, Laursen SB. Association between early ERCP and mortality in patients with acute cholangitis. Gastrointest Endosc 2018; 87(1): 185-92. [CrossRef]

33. Park CS, Jeong HS, Kim KB, Han J-H, Chae HB, Youn SJ, et al. Urgent ERCP for acute cholangitis reduces mortality and hospital stay in elderly and very elderly patients. Hepatobiliary Pancreat Dis Int 2016; 15(6): 619-25. [CrossRef] 


\section{ORIJINAL ÇALIŞMA-ÖZET}

Turk J Surg 2021; 37 (2): 162-168

\section{Yaş ve üzeri hastalarda endoskopik retrograd kolanjiyopankreotografinin (ERCP) güvenliği: Tek merkez deneyimi}

Ahmed Ramiz Baykan ${ }^{1}$, Serkan Cerrah ${ }^{1}$, Sedat Çiftel ${ }^{1}$, Büşra Karahan², Yılmaz Özdemir ${ }^{3}$

1 Erzurum Bölge Eğitim ve Araştırma Hastanesi, Gastroenteroloji Kliniği, Erzurum, Türkiye

2 Erzurum Bölge Eğitim ve Araştırma Hastanesi, lç̧ Hastalıkları Kliniği, Erzurum, Türkiye

${ }^{3}$ Erzurum Bölge Eğitim ve Araştırma Hastanesi, lç̧ Hastalıkları Kliniği, Erzurum, Türkiye

\section{ÖZET}

Giriş ve Amaç: Yaşlı hastalarda (85 yaş ve üzeri) endoskopik retrograd kolanjiyopankreatografinin (ERCP) etkinliğini ve güvenliğini değerlendirmek amaçlandı.

Gereç ve Yöntem: 12 ay içerisinde herhangi bir nedenle ERCP uygulanan hastalar değerlendirildi. ERCP uygulanan hastalar 85 yaş ve üzeri yaşlı grubu ve 85 yaş altı kontrol grubu olarak sınıflandırıldı.

Bulgular: Çalışmaya 504 erkek ve 721 kadın olmak üzere toplam 1225 hasta dahil edildi. Hastanede kalış süresi, ERCP'de ön kesi yapılan hasta sayısı ve mortalite oranı ileri yaştaki (85 yaş) hastalarda kontrol grubuna göre benzer özellikler gösterdi. Prosedüre bağlı komplikasyonlar açısından gruplar arasında pankreatit dışında anlamlı fark yoktu. Yaşlı grupta post-ERCP pankreatit anlamlı olarak daha az görüldü ( $p=0,042)$. Toplam 191 (\% $15,5)$ hastada ön kesi gerekti. Ön-kesi ve kolanjit geçiren hastalarda görülen ERCP sonrası komplikasyonlarda, ileri yaş grubu ( $\geq 85$ yaş) ve kontrol grubu ile karşılaştıııldığında anlamlı bir fark yoktu.

Sonuç: ERCP, genç hastalar kadar yaşı hastalar ( $\geq 85$ yaş) için de güvenli bir prosedürdür.

Anahtar Kelimeler: Endoskopik retrograd kolanjiopankreatografi, yaşlı, endoskopik prosedür

Doi: 10.47717/turkjsurg.2021.5166 